UDC: 338.43:311.21

DOI: $10.26697 /$ ijes.2019.4.35

\section{Features of Statistical Processing of Research Results}

\author{
Associate Professor Khmelianchyshyn Yu. $\mathbf{V}^{\mathbf{1}}$, \\ Kliutsovych H. M. ${ }^{2}$, Khmelianchyshyna N. M. ${ }^{3}$ \\ ${ }^{1}$ State Agrarian and Engineering University in Podilia, \\ Ukraine \\ ${ }^{2}$ Borshchiv Agricultural College, Ukraine \\ ${ }^{3}$ College of State Agrarian and Engineering University \\ in Podilia, Ukraine
}

\begin{abstract}
Background:

An experiment is the most important way to get new knowledge in the realm of natural and technical sciences. Experimental research gives evaluation criterion of validity and acceptability of any theory and theoretical assumption in practice. One of the main stages of any experiment is statistical processing of the experimental data. It is directed, as a rule, on the structure of mathematical model of the researched object or fact, and also it is directed to answer the question: "Is the reliable data obtained within required level of probability?"
\end{abstract}

\section{Results:}

The evaluation of qualification job recently has testified that methodically justified techniques are not chosen for processing of the experimental data, and also the contenders' level of knowledge of techniques such processing of research results leaves much to be desired.

We lose knowledge from technology of receiving statistical indicators with huge using of computer programs and, as a consequence, we stop using them for searching right interpretation of experimental results. Statistical criteria of the indicators transform to intellectual shackles instead of transformation to quick response tool. It hinders free and usually subjective interpretation of the results and conclusions.

For example: it is investigated three-factor complex (A, $\mathrm{B}, \mathrm{C})$ and the indicator is given $\mathrm{LSD}_{\mathrm{A}}, \mathrm{LSD}_{\mathrm{B}}, \mathrm{LSD}_{\mathrm{C}}$, $\mathrm{LSD}_{\mathrm{AB}}, \mathrm{LSD}_{\mathrm{AC}}, \mathrm{LSD}_{\mathrm{BC}}$ i $\mathrm{LSD}_{\mathrm{ABC}}$. There is a question, where is LSD general which is necessary for statistical evaluation of reliability of differences between any variants? There is not! There is a such situation because the investigator does not understand the technology of Multivariate analysis of variance (MANOVA) as a component of solution of consecutive one-factor complexes.

The first cycle of the analysis of variance is determined for public use $\bar{x}, \mathrm{~S}, \mathrm{~S}_{\bar{x}}^{-}, \mathrm{Sd}, \mathrm{V}$, Dyx general, $\mathrm{LSD}_{05}$ general, $\mathrm{S}_{\mathrm{x}} \%$. All indicators are analytically interrelated and therefore easily recovered. For example, a researcher has a problem with accuracy (S\%), and he does not bring it to work without knowing that the indicator is easily recovered. In the research methodology, the author indicates the number of gradations of the factor $-1=5$, repetition $-n=4$. In the yield table, LSD05 $=3.7 \mathrm{c}=208 \mathrm{Cwt} / \mathrm{ha}$.
According to these data, we determine the accuracy of $\mathrm{S}_{\mathrm{x}} \%: \mathrm{LSD}=\mathrm{t}_{05} * \mathrm{Sd}$, where $\mathrm{t}_{05}=2.18$ for 12 degrees of freedom $\left(\gamma_{z}={ }^{\gamma}{ }^{-}{ }^{\gamma} p^{-\gamma}{ }_{v}=19-3-4=12\right)$ $\mathrm{Sd}=\mathrm{LSD}_{05} / \mathrm{t}_{05}=3.7 / 2.18=1.7 \quad \mathrm{Cwt} / \mathrm{ha} ; \quad \mathrm{S}_{\mathrm{X}}^{-}$ $=\mathrm{Sd} / \sqrt{ } 2=1.7 / 1.41=1.21 \quad$ ц $/$ а $; \quad \mathrm{S}_{\mathrm{x}} \%=\mathrm{S}_{\mathrm{x}} / \overline{\mathrm{x}} * 100=$ $1.21 / 208=0.58 \%$.

Having received such a result, it became clear to any reviewer: the researcher did not want to show incredible "accuracy", and in the worst case testifies that the experiments were not conducted and the resultant materials were falsified.

After the publication of the textbook of B. O. Dospehov "Field Experience Method (with Basics of Statistical Processing of Research Results)" method of variance analysis was constantly associated with its surname. Even a peculiar cliché appeared: "the statistical analysis was performed by variance analysis according to B. O. Dospehov. The name R. A. Fisher was forgotten, who is a true developer of the method whose essence was to find the ratio of the larger variance of the experiment to the smaller one and to compare it with a certain number of the Fisher special table. If the determined number was greater than the Fisher criterion $(\mathrm{F})$, the null hypothesis $(\mathrm{HO}: \mathrm{d}=0)$ was rejected, that is, it proved that the investigated factor actively influences the variability of the research object.

\section{Conclusions:}

As a conclusion, we should note: 1) analysis of variance is used in various forms depending on the structure of the experiment. Choosing the right form is the key to successful application of the analysis; 2) all indicators are analytically interrelated and therefore easily recovered; 3 ) in any experiment the average values of the studied values change under the influence of systemic (organized) and non-systemic (random) reasons. Separating them and determining the force of action is the main task of analysis of variance.

\section{Information about the authors:}

Khmelianchyshyn Yurii Volodymyrovych - Doctor of Philosophy in Plant Growing, Associate Professor of the Department of Crop and Fodder Production, State Agrarian and Engineering University in Podilia, Kamianets-Podilskyi, Ukraine.

Research interests: higher education and training, scientific research in the field of agronomy; https://orcid.org/0000-0003-2860-2065.

Kliutsovych Halyna Mykolaivna - Lecturer, Borshchiv Agricultural College, Borshchiv, Ukraine.

Research interests: education and training; https://orcid.org/0000-0002-1831-9373.

Khmelianchyshyna Nataliia Mykhailivna - Deputy Director, Teacher, College of State Agrarian and Engineering University in Podilia, KamianetsPodilskyi, Ukraine.

Research interests: education and training, the latest teaching methods; https://orcid.org/0000-0001-94239554.

\section{Corresponding Author:}

Khmelianchyshyn Yurii Volodymyrovych

Corresponding Author's Email:

334320@i.ua 